\title{
Pengaruh Tradisi kliwonan pada masyarakat cirebon Oleh:farrel farazandi
}

\author{
Prodi studi agama-agama fakultas ushuluddin \\ Universitas Darussalam gontor \\ farazandifarrel@gmail.com
}

\begin{abstract}
Artikel ini Membahas tentang Kliwonan atau tradisi yang biasa di lakukan tiap 35 hari sekali yaitu pada malam jumat kliwon. Pada tanggal tersebut masyarakat datang dari berbagai macam daerah dan kalangan untuk mengikuti acara kliwonan. Kota Cirebon merupakan kota wali karena kota ini merupakan pusat penyebaran islam di daerah jawa barat berkat kehadiran sunan gunung djati, tetapi apakah masyarakat Cirebon memegang teguh agama mereka atau terjadi akulturasi dalam agama mereka, Penulis Menggunakan metode studi literatur berdasarkan hasil yang diperoleh dari literatur penulis menyimpulkan bahwa tradisi kliwonan merupakan hasil percampuran antara tradisi nenek moyang terdahulu dengan agama islam dalam bentuk ziarah, tetapi tanpa mengetahu asal usul dari tradisi tersebut sehingga mereka hanya mengikuti tradsi orang-orang terdahulu sampai para tokoh terkemuka agama menentang ada nya kliwonan karena melakukan penyimpangan ajaran agama dan melakukan penghormatan dan pemujaan terhadap wali serasa mengalahkan pemujaan terhadap pencipta wali tesebut. Tetapi di lain kliwonan memberi keuntungan terhadap masyarakat yang tinggal di sekitar wilayah tersebut.
\end{abstract}

Kata kunci:Tradisi Kliwonan,Aqidah,Gunung Djati Cirebon,Slametan dan Sinkritisme

\section{Pendahuluan}

Cirebon dikenal sebagai Kota Wali dan Kota Pelabuhan menyimpan sejarah Panjang di masa lalu, khususnya mengenai peristiwa cikal bakal penyebaran islam di jawa barat. Hal itu tidak bisa dilepaskan dari peran pedagang muslim, ulama, dan tokoh pribumi. Mereka berjuang dalam mewujudkan sebuah nagari bercorak islam dan bebas dari kekuasaan pemerintah kerajaan sunda-galuh.setelah nagari Cirebon terbentuk, kota ini menjadi sering disinggahi pedagang asing melalui jalur perlintasan perdagangan yang bertaraf internasional ${ }^{1}$.

Tetapi waktu pun berlalu kini masyarakat Cirebon menghadapi berbagai benturan keagamaan yang dimana mereka mencampurkan antara agama dan budaya seperti syawalan gunung djati tradisi ini merupakan ziarah pada bulan syawwal setelah idul fitri ke makam sunan gunung djati. Pada bulan ini masyarakat Cirebon biasanya melakukan ziarah dan tahlilan di makam sunan gunung djati Cirebon. Setiap Syawalan biasanya tempat ziarah makam Sunan Gunung Jati dipenuhi para peziarah hampir dari semua daerah Cirebon dan daerah lain di sekitarnya. Tradisi yang dinamakan syawalan ini telah berlangsung selama ratusan tahun dan selain untuk menghormati Sunan Gunung Jati para peziarah datang ke makam ini untuk mengharapkan berkah yang melimpah ${ }^{2}$.

Selain tradisi syawalan terdapat berbagai macam tradisi lain yang seperti Ganti Walit adalah upacara adat di makam kramat Trusmi Cirebon. Upacara yang dilaksanakan setiap

\footnotetext{
${ }^{1}$ Zulfah siti,Skripsi:"'islamisasi di Cirebon(Studi Tentang Peran Dan Pengaruh Walangsungsang)" (UIN sunan kalijaga)

2 Afghoni Afghoni."Makna Filosofis Tradisi Syawalan”Jurnal studi agama dan masyarakat 2017 Volume 13, No.5, https://e-journal.iain-palangkaraya.ac.id/
} 
tahun di Makam Kramat Trusmi ini bertujuan untuk mengganti atap makam keluarga Ki Buyut Trusmi yang menggunakan Welit (anyaman daun kelapa). Upacara ini dilakukan oleh masyarakat Trusmi Cirebon. Biasanya dilaksanakan setiap tanggal 25 bulan Maulud ${ }^{3}$.

Pada Waktu Mbah kuwu Cirebon yang bernama Pangeran Cakrabuana hijrah dari Cirebon ke sebuah Daerah yang sekarang disebut Trusmi, mbah Kuwu Cirebon berganti pakaian memakai baju kyai yang tugasnya menyebarkan ajaran agama Islam. Hingga sekarang ia dikenal dengan nama Mbah Buyut Trusmi.kemudian ada tradisi Rajaban adalah tradisi upacara dan ziarah ke makam Pangeran Panjunan dan Pangeran Kejaksan di Plangon. Rajaban umumnya dihadiri oleh para kerabat dari keturunan kedua pangeran tersebut. Ziarah ini dilaksanakan setiap tanggal 27 Rajab $^{4}$

Selain itu ada juga Tradisi kliwonan ${ }^{5}$ merupakan suatu tradisi berziarah di Situs Keramat Gunung Jati yang dilaksanakan setiap 35 hari sekali yaitu pada malam Jumat Kliwon, yang jatuh pada hari ke-5 Pasaran Jawa. Para penziarah yang datang mengikuti kliwonan jumlahnya mencapai ribuan orang, yang berasal dari berbagai kalangan

Dengan melihat berbagai perkembangan yang terjadi rupanya masyarakat Cirebon kini telah mencampur adat istiadat mereka dengan upacara keagamaan yang dimana ini merupakan salah satu dari paham sinkritisme yang menjalar pada benak masyarakat daerah Cirebon

\section{Sejarah Islam di Cirebon}

Cirebon, seacara geografis terletak di tepian pantai utara jawa (pantura), yang dilengkapi dengan sungai-sungai yang sangat penting perananya sebagai jalur transportasi ke pedalaman yang letaknya di sekitar Pelabuhan Cirebon, islam adalah agama baru di Cirebon diperkenalkan beberapa saat sebelum kedatangan sunan gunung djati, Tokoh-tokoh yang mengawali perkenlan islam di wilayah Cirebon adalah syekh nurul jati (syeikh datul kahfi) beserta 13 pengikutnya yang disusul dengan kedatangan 4 orang juru dakwah yang berasal dari baghadad yaitu sayid abdul Rahman yang lebih dikenal sebagai (pangeran kejaksan), sayid abdul Rahim (pangeran kejaksan) sayid Abdullah dan siti Baghdad. Di sebelah utara kaki gunung jati para juru dakwah tersebut mendirikan pondok pesantren dan dua buah sumur. Pondok pesantren yang didirikan dibuat samara dengan maksud untuk menghindari ancaman dari orang-orang yang tidak menyenangi dan menyukai agama islam, Islam mengalamai perkembangan yang menyenangkan dan menggembirakan di Cirebon Ketika penyebarannyan dilakukan oleh syekh syarif hidayatulah atau yang lebih di kenal sebagai sunan gunung djati

Langkah awal paling bersejarah yang diambil oleh Sunan Gunung Jati adalah pada tahun 1483 beliau menghentikan pengiriman upeti garam dan terasi yang tiap tahun harus dikirimkan ke ibukota Pakuan Pajajaran, sebagai persembahan dan tanda takluknya kerajaan kecil kepada kerajaan besar. Dengan demikian sejak saat itu Cirebon di bawah kepemimpinan Sunan Gunung Jati menjadi negara merdeka dan tidak lagi berada di bawah pengaruh Kerajaan Pajajaran yang Hindu. Untuk mengantisipasi serangan dari Pajajaran akibat dari penghentian pengiriman upeti tersebut dan memelihara keamanan negara maka dibentuklah pasukan keamanan yang disebut dengan pasukan Jagabaya, dengan komandan tertingginya dipegang oleh Tumenggung, yang jumlah dan kualitasnya memadai baik untuk

\footnotetext{
${ }^{3}$ Pramadya betro .Macam-Macam-Upacara-Adat-Di-Cirebon.http://macam-macam-tariandaerah.blogspot.com/

${ }^{4}$ Admin.Kondisi Objektif Desa Trusmi Diakses dari syekhnurjati.ac.id/esscamp/risetmhs/ BAB314122210979.pdf

${ }^{5}$ Ali Abdullah Tradisi Kliwonan Gunung Jati Model Wisata Religi Kabupaten Cirebon (Cirebon : Pemkab. Cirebon, 2007)
} 
ditempatkan di pusat kerajaan, di pelabuhan maupun di wilayah-wilayah yang dikuasai Cirebon ${ }^{6}$.

\section{Pengertian ziarah}

Ziarah diambil dari kata zaara-yazuuru-ziyaaratan yang berarti menziarahi/mengunjungi, Ziarah menurut kamus besar bahasa Indonesia, ziarah artinya kunjungan ke tempat yang dianggap keramat atau mulia (makam dan sebagainya), berziarah artinya berkunjung ke tempat yang dianggap keramat atau mulia (seperti makam) untuk berkirim doa, menziarahi artinya mengunjungi makam (tempat keramat dan sebagainya) sambil mengirim doa; berziarah ke; melakukan ziarah, penziarah artinya orang yang berziarah; orang yang gemar berziarah, Penziarah artinya peziarah, dan penziarahan artinya proses, cara, perbuatan menziarahi.

Dalam ritual ziarah ke makam wali dapat dibedakan menjadi dua tujuan, pertama ritual penghormatan (yaitu mendoakan arwah wali) dan kedua meminta berkah. Dengan adanya dua tujuan ini terjadi karena adanya pemahaman dan keyakinan dari masyarakat yang berbeda. Berdasarkan hal tersebut dapat ditarik kesimpulan bahwasanya ziarah adalah kegiatan menengok atau mengunjungi tempat-tempat tertentu seperti kuburan, petilasan dan lain sebagaimana. Sebenarnya ziarah itu untuk mengingat kepada kematian sedang keadaan masyarakat dan prilaku yang berkaitan dengan aktivitas ziarah ini sangat identic dengan tabarruk $^{7}$. Kondisi tersebut juga terjadi di makam sunan gunung djati. Hal sendiri diyakini sebagai salah satu wali yang pernah berperan dalam menyebarkan agama islam di jawa ${ }^{8}$

Dengan demikian, ziarah kubur adalah kunjungan ke tempat pemakaman umum/pribadi yang dilakukan secara individu atau kelompok masyarakat pada waktu tertentu, dengan tujuan mendoakan saudara atau keluarga yang telah meninggal dunia supaya diberikan kedudukan atau posisi yang layak di sisi Allah SWT., sehingga arwahnya diharapkan bisa tenang dengan adanya permohonan doa dari keluarganya yang masih hidup.

\section{Slametan dan sinkritisme}

Tradisi dan budaya slametan seperti yang telah diuraikan di atas bukan saja merupakan merupakan tradisi yang berasal atau diadopsi dari agama-agama nenek moyang masyarakat di Indonesia yaitu agama hindu dan budha tetapi juga merupkan tradisi campuran dari tradisi yang berkembang dalam agama islam ${ }^{9}$. Tidak sedikit unsur-unsur yang terdapat dalam agama hindu dan buddha yang sampai saat ini mmasih melekat dan senantiasa terus dipertahankan oleh Sebagian masyarakat muslim yang masih awam dari sisi agama dan kepercayaanya

dalam catatan Emanuel gerrit singgih sinkretis atau sinkretisme berasal dari bahasa yunani synkretismos, yang berarti perserikatan kota-kota di pulau kreta. Dari asal kata tersebut datanglah kata synkretiezen,"Bersatu untuk menghadapi musuh Bersama". Pada saat itu kata singgih, penduduk kota kreta saling bersaing bahkan saling berhadapan dan bermusuhan antara satu dan yang lainnya. Tidak ada kata kebersamaan dan persamaan, namun untuk menghadapi ancaman musuh dari luar pulau kreta merekea berserikat walaupun tadinya berbeda-beda kepentingan. Antara satu dengan yang lainya ${ }^{10}$

dengan demikian, maka sejatinya istilah sinkritisme bukan merupakan istilah yang berasal dari teologis, tetapi istilah itu sesungguhnya cenderung sangat praktis. Namun

\footnotetext{
${ }^{6}$ Admin.CirebonMasaTradisional.Diaksesdari syekhnurjati.ac.id/esscamp/risetmhs/BAB21413313006.pdf

${ }^{7}$ Tabarruk dapat diartikan untuk mencari berkah

${ }^{8}$ Aminullah /Peranan Sunan Gunung Jati Dalam Islamisasi Di Kesultanan Cirebon/UIN Alauddin Makassar

${ }^{9}$ Jarman aroisi.Aliran Kepercayaan, Kebatinan dan Kebatinan.(Ponorogo : Darussalam Press)123

${ }^{10}$ Neneng irawati,"Sinkritisme islam dan jawa dalam pernikahan adat jawa",IAIN Purwokerto
} 
kemudian hari istilah tersebut berkembang dan dipakai dalam bidang agama dan teologis untuk menunjukkan paling tidak memiliki empat $\operatorname{arti}^{11}$ :

A.sebagai usaha mendamaikan pendapat-pendapat atau keyakinan yang saling bersebrangan dan bertentangan.

b.sebagai usaha mengkompromikan yang ceroboh:suatu ekletisme yaitu sikap memilih-milih beberapa pokok dari satu sisi dan menerima dari sisi lain, menolak beberapa sisi dan menerima dari sisi lain

c.proses suatu perkembangan dari pertumbuhan yang terjadi di dalam sejarah, yang bersangkut-paut dengan keyakinan dan praktek melalui pergaulan yang lain

d.persatuan dan percampuran dari bentuk-bentuk yang tadinya berbeda-beda setelah memperhatikan

setelah memperhatikan pengertian sinkretis seperti yang diuraikan diatas, dapat ditarik sebuah gambaran bahwa ternyata tidak sedikit masyarakat muslim jawa yang terlibat dan melakukan praktik-praktik sinkretis. Terlepas apakah mereka mengetahui makna serta hakikat dari sinkretis atau tidak, dan apakah mereka juga mengetahui mengenai hukum Tindakan yang sinkret atau tidak. Dari peran itu juga mereka dalm melaksanakan Tindakantindakan yang seperti itu, tampaknya bukan saja mereka tidak mengetahui asal-muasal kegiatan itu dilakukan, tetapi justru mengetahui nya bahwa kegiatan itu berasal dari warisan nenek moyangnya, maka kemudian mereka tertarik untuk menguri-ngurinya menjadi semacam tradisi dan rutinitas yang harus di lakukan ${ }^{12}$

\section{Pengertian Slametan}

Salah satu upacara tradisi masyarakat muslim jawa yang sampai saat ini masih dijaga adalah tradisi slametan. Slametan merupakan kegiatan social dalam bentuk upacara yang dilakukan secara tradisional dengan maksud mendapat ketenangan, ketentaram, kebahagian dan keseimbangan hidup ${ }^{13}$ di berbagai daerah di Indonesia masih banyak sekali, khusus nya bagi mereka yang awam dalam bidang keagamaan melakukan kegiatan slametan sebagai bentuk menyampaikan hajatan atau tujuan tertentu.

Tradisi slametan yang merupakan sebuah ritual adat jawa, atau menurut orang Jawa Islam sering menyebutnya dengan istilah syukurannya orang Jawa. Karena setiap ada peristiwa-peristiwa penting Islam dan peristiwa kehidupan orang Jawa sendiri selalu melaksanakan ritual syukuran tersebut atau slametan. Budaya masyarakat Islam Jawa yang masih sering mengikuti dan mentradisikan kegiatan tersebut dapat ditinjau dari segi keawetan masyarakat tersebut dalam segala pengaruh. Lihat saja di daerah keratonan dan daerah petani masih sangat terlihat jelas kehasan dan keemasan tradisi tersebut untuk mewarnai kehidupan mereka ${ }^{14}$.

Sebuah realitas yang unik ini merupakan pembumian akan tradisi lokal. Siapa yang tidak bangga dengan kultur yang dimiliki daerah Jawa yang masih sempat kita telurusi perkembangan dan keunikannya. Dengan memanfaatkan sedikit rezeki yang diberikan kepada Sang Maha Kaya tersebut, kita bisa menyedekahkan apa yang kita punya melalui acara slametan tersebut. Meskipun bagi masyarakat Jawa masih banyak yang menggunakan yang mencampurkan dengan simbolis mistik kejawen seperti adanya kemenyan dan bungabunga an. Akan tetapi mereka masih tetap memasukkan unsur islami dan memadukannya dengan adat Jawa tersebut.

\footnotetext{
${ }^{11}$ Jarman aroisi..Aliran Kepercayaan, Kebatinan dan Kebatinan.(Ponorogo : Darussalam Press)126

12 Jarman aroisi.Aliran Kepercayaan, Kebatinan dan Kebatinan.(Ponorogo : Darussalam Press) 126

${ }^{13}$ Jarman aroisi.Aliran Kepercayaan, Kebatinan dan Kebatinan....85

${ }^{14}$ Dewi haryani.Religi unik "slametan" masyarakat jawa/ dewiharyani8.blogspot.com/
} 
Beberapa tradisi slametan yang sering kita jumpai misalnya acara slametan mithoni (uumur kehamilan seorang wanita selama 7 bulan), atau menjelang pernikahan seseorang atau pada waktu-waktu kebesaran Islam yaitu maulid nabi dan sebagainya. Keadaan tersebut dipilih sebagai waktu-waktu penting orang Jawa sebagai simbolisasi do'a yang diperuntukkan kepada Sang Maha Agung Allah SWT untuk memohon keselamatan bagi keluarga atau seseorang yang mempunyai hajat tersebut agar diijabahi (dikabulkan) oleh Allah.

Menelisik tradisi slametan yang menjadi kekhasan masyarakat Jawa memiliki nilainilai yang unik diantaranya mempunyai nilai ketuhanan dengan maksud sebagai lantaran untuk memanjatkan do'a kepada Ilahi Rabbi untuk memohon terhindar dari hal-hal yang tidak diinginkan. Selain itu mengandung nilai solidaritas sosial karena dalam upacara atau ritual slametan tersebut menjalin silaturahmi antar warga sekitar. Dimana keluarga yang mempunyai kebutuhan mengajak para tetangga dan sanak saudara untuk berkumpul bersama tanpa membeda-bedakan satu sama lain. Dengan menghidangkan nasi tumpeng atau nasi kuning dengan dilengkapi ayam ingkong (ayam dimasak utuh) sebagai prasyarat acara slametan tersebut.

Namun tidak semua orang muslim Jawa mengamini tradisi tersebut, bahkan ada yang menganggap tradisi slametan tersebut merupakan aliran yang sesat dan bukan ajaran Islam. Menanggapi hal tersebut sewajarnya kita harus menengok kembali bagaimana nilai yang terkandung pada tradisi tersebut. Tidak hanya memandang dari kaca mata Islam saja, akan tetapi perlunya kita mengkaji lebih dalam akar dari tradisi tersebut dan mengambil sisi positifnya. Karena Jawa lahir terlebih dahulu sebelum Islam masuk, patutlah sewajarnya orang Jawa masih belum beradaptasi dengan ajaran Islam. Karena Islam merupakan agama yang ramah dan adat Jawa sangat terbuka dan kuat, maka apa salahnya tradisi slametan masih ditradisikan sampai sekarang dan bahkan segai rutinitas orang Jawa dalam memaknai Islam.

Sistem kepercayaan animisme dan dinamisme sangatlah melekat dalam kehidupan masyarakat jawa. Mereka beranggapan bahwa setiap benda yang ada di dunia ini, selain memiliki nyawa, juga memiliki kekuatan gaib (roh) dan berwatak (baik dan buruk), Bahkan, Ketika agama hindu dan islam masuk dam mempengaruhi kepercayaan masyarakat jawa, keadaaan tersebut tidaklah serta merta menghapus keseluruhan system kepercayaan peninggalan nenek moyang mereka. Dari sini terciptalah percampuram budaya atau akulturasi antara agama pendatang dengan system kepercayaan nenek moyang. Dalam hal ini, ritual selametan merupakan salah satu tradisi hasil akulturasi budaya yang masih tetap terlestarikan hingga saat ini

Tujuan utama dari selametan adalah untuk mendapatkan keselamatan dan perlindungan dari allah yang maha kuasa. Karena tujuannya adalah keselamatan, praktik selametan menghiasi hampir seluruh kegiatan atau kejadian yang dianggap penting ${ }^{15}$

\section{Tradisi kliwonan}

Tradisi Kliwonan Gunung Jati, sangat bermakna bagi masyarakat pengunjung atau penganut paham mistik serta pengikut aliran tarikat dalam Islam, merupakan peluang terbuka lahan penghasilan bagi juru kunci makam Sunan Gunung Jati, Kelompok masyarakat yang berstruktur fungsional di sekitar lokasi, sebagai pedagang pelayanan jasa tempat tinggal, pengelola parkir. ${ }^{16}$

\footnotetext{
${ }^{15} \mathrm{https}: / /$ blogkulo.com/tradisi-selamatan-jawa/

${ }^{16}$ A.A Halim.Tradisi kliwonan di kompleks Gunung Jati Cirebon dalam perspektif filsafat budaya.(Univeristaas Gadjah mada)
} 
Menurut masyarakat Indonesia pada umumnya, sunan gunung djati dipandang sebagai tokoh yang berjasa dalam rangka menyebarkan agama islam di pulau jawa. Mengingat peranannya yang sangat besar maka ada Sebagian masyarakat Indonesia yang mengkramatkan makamnya. Salah satu tokoh walai yang dikrematkan adala syarif hidayatullah, atau yang lebih dikenal dengan nama sunan gunung djati. Makam sunan gunung djati yang berada di Cirebon selalu dipadati peziarah yang datang secara perorangan, Bersama keluarga atau rombongan dari satu desa atau satu tarekat mencarter bus Bersamasama. Kebanyakan peziarah hanya mengadakan kunjungan singkat, tetapi ada juga yang melakukan nyepi selama satu atau beberapa malam pada komplek makam. Di samping itu ada sejumlah peziarah dalam skala besar pada hari-hari tertentu misalnya pada malam juma't kliwon, bulan syawwal, sya'ban dan lain-lain. Setiap malam juma't kliwon, orang berdesakdesakan di depan gerbang makan sunan gunung djati, agar bisa mendapatkan tempat duduk untuk melaksanakan tahlil Bersama di makam sunan gunung djati

Tradisi kliwonan merupakan suatu bentuk kegiatan seremonial keagamaan yang dilakukan oleh sekelompok masyarakat muslim yang diyakini sebagai amalan ibadah berupa ziarah ke makam wali, berdzikir, tahlil, shalat dan termasuk juga mandi kembang di sekitar kuburan wali (Sunan Gunung Jati). Mereka menganggap berziarah ke makam wali adalah suatu amalan shaleh dan mendatangkan berkah. Sugesti tabarruk ini memunculkan nilai spirit yang kuat bagi kehidupan mereka, dimana untuk mencapai tujuan kebaikan secara material sangat mendominasi dalam do'a dan harapan mereka. Dari fenomena tersebut, kelompok elit keagamaan (fundamentalis) memandang tradisi kliwonan adalah suatu bentuk penyimpangan terhadap ajaran agama, pemujaan atau penghormatan terhadap wali serasa mengalahkan pemujaannya kepada Pencipta wali sebagai al-Khaliq, al-Razzaq, al-Wahhab, sehingga mengandung unsur syirik ${ }^{17}$

seiring jalannya waktu, tradisi kliwonan tetap menjadi alternatif sebagai bentuk seremoni religi yang sarat dengan nilai material baik bagi pengunjung maupun masyarakat setempat. Tradisi kliwonan merupakan transformasi dari budaya mistic Hindu yang sangat melekat dan mendominasi masyarakat Jawa khususnya sebelum tersebarnya Islam. Animisme dan dinamisme begitu me-ruh dalam seremoni tradisi kliwonan ini. Ruh wali dan makam dianggap keramat yang memberikan semangat.

Ziarah ke makam wali sudah ada sejak dulu dan menjadi aktivitas yang dilakukan ileh masyarakat jawa.ziarah bahkan menjadi salah satu kegiatan yang sudah menjadi agenada tersendiri dalam memnuhi kegiatan keagamaanya. Ziarah sebagai sarana penghormatan terhadap leluhur, dilakukan juga ziarah ke makam-makam tua dan tempat tokoh dimakamkan atau tempat-tempat keramat lainnya. Biasanya mereka berziarah ke makam para walisongo yang dianggap mempunyai kelebihan dan kesaktian serta merupkan tokoh yang menyebarkan agama islam.

Makam sunan gunung djati ini setiap malam jumat kliwon selalu padat dan ramai dikunjungi oleh masyarakat yang datang dari berbagai macam daerah ${ }^{18}$.

\section{Islam dan budaya jawa}

Nabi Muhammad pernah berpesan, jangan sampai ada diantara umat islam yang memperingati hari kelahiranya sebagaimana orang-orang Nasrani memperingati hari kelahiran isa al-Masih, bahkan dengan tegas beliau menyatakan, saya ini hanyalah hamba

\footnotetext{
${ }^{17}$ Sachistiani.Tradisi ziarah jumat kliwon ke makam sunan gunung djati Cirebon(universitas islam negeri sunan kalijaga Yogyakarta).

${ }^{18}$ Sachistianai.Tradisi ziarah jumat kliwon ke makam sunan gunung djati Cirebon(universitas islam negeri sunan kalijaga Yogyakarta
} 
biasa, maka katakanlah hamba allah dan rasulnya. Namun seiring dengan berjalanya waktu, pesan tersebut diabadikan oleh Sebagian umatnya, dengan menjadikan tanggal 12 Rabiul awwal sebagai hari peringatan lahirnya nabi Muhammad SAW. Pada perkembanganya, Sebagian besar umat islam, secara mudah menyebutkan bulan dan tanggal tersebut sebagai hari maulud nabi Muhammad ${ }^{19}$.

Sama khalayaknya tradisi kliwonan, tradisi kliwonan merupakan hasil dari pemahaman masyarakat Cirebon tentang ziarah ke makam sunan gunung djati tiap malam jumat kliwon, yang menarik adalah berkumpulnya warga masyarakat sejak usia kanakkanak, muda-mudi, bahkan tidak ketinggalan yang tua pun mengikuti dan mensuksekan tradisi ini. Namun yang disayangkan mereka melakukan kegiatan itu, hanya sebatas mengikuti arus yang berjalan, tanpa di barengi pengetahuan yang memadai sehingga tidak heran juga kalau apa yang mereka lakukan itu tidak berarti dan bermakna, karena memang realitanya, mereka benar-benar tidak mengetahui arti dan maksudnya. Akibatnya tradisi kliwonan yang dulu memilik akar sejarah dakwah islam itu, seiring dengan berjalanya waktu, saat ini telah berubah dan menyimpang dari nilai sejarahnya, bergeser menjadi komuditi wisata yang jauh dari nilai-nilai dakwah. ${ }^{20}$

\section{Kesimpulan}

Setelah kita mengetahui tentang tradisi kliwonan di Cirebon kita bisa mengambil suatu kesimpulan dari tradisi daerah ini disamping tradisi ini ditentang oleh para tokoh agama karena memandang bahwasanya tradisi kliwonan merupakan bentuk penyimpangan ajaran agama, pemujaan atau penghormatan terhadap wali serasa mengalahkan pemujaan terhadap pencipta wali itu sendiri sehingga mengandung unsur syirik, tetapi hal itu muncul karena mereka mengikuti tradisi orang-orang terdahulu tanpa mengetahui benar atau salah nya hal tersebut.

Tetapi di sisi lain tradisi kliwonan sangat bermakna bagi masyarakat pengunjung atau penganut paham mistik serta pengikut aliran tarikat dalam Islam, serta merupakan peluang terbukanya sumber pendapatan bagi juru kunci makam sunan gunung djati, kelompok masyarakat yang mempunyai peran di wilayah tersebut serta pedagang dan tukang parkir.

\footnotetext{
${ }^{19}$ Jarman Arroisi. ALIRAN KEPERCAYAAN \& KEBATINAN: Membaca Tradisi dan Budaya Sinkretis Masyarakat Jawa .

${ }^{20}$ Jarman Arroisi.ALIRAN KEPERCAYAAN \& KEBATINAN: Membaca Tradisi dan Budaya Sinkretis Masyarakat Jawa
} 


\section{Daftar Pustaka}

Abdullah,Ali Tradisi Kliwonan Gunung Jati Model Wisata Religi Kabupaten Cirebon (Cirebon : Pemkab. Cirebon, 2007)

Admin."Cirebon Masa Tradisional",(Smart campus IAIN Syekh Nurjati)

Afghoni,Afghoni, 2017"Makna Filosofis Tradisi Syawalan"Dalam Jurnal studi agama dan masyarakat Volume 13, No.5, Juni, IAIN palangkaraya

Aminullah,Aminullah, 2015. "Peranan Sunan Gunung Jati Dalam Islamisasi Di Kesultanan Cirebon",Skripsi.Makassar: UIN Alauddin Makassar

Arroisi,Jarman, 2015."Aliran Kepercayaan \& Kebatinan: Membaca Tradisi dan Budaya Sinkretis Masyarakat Jawa",Jurnal Al-Hikmah Volume 1,No.1, Universitas Muhammadiyah surabaya

Arroisi,Jarman, Aliran Kepercayaan,Kebatinan Dan Sinkritisme,(Ponorogo:Darussalam Press, 2019)

Betro,Pramadya,"Macam Ipacara Adat Di Cirebon" http://oleholehmami.com/blog/macam-macam-upacara-adat-di-cirebon.Diakses pada 15 Agustus 2021

Halim,A.A, 2008. "Tradisi kliwonan di kompleks Gunung Jati Cirebon dalam perspektiffilsafat budaya",Disertasi. Universitas Gadjah mada

Haryani,Dewi.2015 "Religi unik "slametan" masyarakat jawa" https://dewiharyani8.blogspot.com/2015/03/religi-unik-slametan-masyarakatjawa/.Diakses pada 8 Agustus 2021

Irwanti,Neneng, 2019."Sinkritisme islam dan jawa dalam pernikahan adat jawa" Skripsi. Purwokerto: IAIN Purwokerto

Pc, Vian,Kondisi Objektif Desa Trusmi,(SC IAIN Syekh Nurjati )

Sachistiani,Sachistiani, 2015. "Tradisi ziarah jumat kliwon ke makam sunan gunung djati Cirebon 'Skripsi. Yogyakarta: UIN Sunan Kailijaga

Zulfah,Siti, 2015. "islamisasi di Cirebon(Studi Tentang Peran Dan Pengaruh Walangsungsang)" Skripsi. Yogyakarta: UIN Sunan Kalijaga 